\title{
Seasonal and Spatial Variations of N, P, K and Cd Concentrations in Water of the Mahakanumulla Cascade in the Dry zone of Sri Lanka
}

\author{
W.M.G.D. Wijesundara ${ }^{*}$ K.A. Nandasena ${ }^{1}$ and A.N. Jayakody ${ }^{1}$ \\ Postgraduate Institute of Agriculture \\ University of Peradeniya \\ Sri Lanka
}

\begin{abstract}
Systematic work on water quality aspects, particularly on the accumulation and fluctuation of plant nutrients and heavy metals, has not being carried out at the Mahakanumulla tank cascade in the dry zone of Sri Lanka. Therefore, the main objective of this research was to study the seasonal changes of the concentration of major plant nutrients viz., Nitrogen $\left(\mathrm{NO}_{3}^{-}\right)$, Phosphorus $\left(\mathrm{PO}_{4}^{3-}\right)$, Potassium $\left(\mathrm{K}^{+}\right)$, and heavy metal Cadmium $\left(\mathrm{Cd}^{+2)}\right.$ in water along the cascade system. The concentrations of $\mathrm{NO}_{3}^{-}, \mathrm{PO}_{4}^{3-}, \mathrm{K}^{+}$and $\mathrm{Cd}^{+2}$ in water samples showed significant spatial and temporal variations over the study period and showed a bimodal pattern. The highest concentrations of the measured parameters were observed in months of April and May in the Yala season. Low nutrient concentration observed in the Maha season could be due to dilution effect caused by the comparatively high volume of tank water. Spatial distribution of $\mathrm{NO}_{3}^{-}, \mathrm{PO}_{4}{ }^{3-}, \mathrm{K}^{+}$and $\mathrm{Cd}^{+2}$ concentrations in the water of three sampling locations of each paddy tract showed a significant increasing trend from the first sampling point to third point of the paddy field.
\end{abstract}

Keywords: Seasonal changes, plant nutrients, heavy metal, tank cascade system

\section{INTRODUCTION}

The dry zone of Sri Lanka is located in lowest part of island and consists large number of inland valleys. This type of topography, climatic condition, soil and surface hydrological conditions favour the establishment of cascade irrigation system with small tanks in dry zone of Sri Lanka (Pannabokke, 2002). A tank cascade is a series of small tanks that are constructed at successive locations down one single common water course. Small tank systems are perceived as human adaptation to rain fall pattern, a water harvesting system that enables through irrigation, to change the uneven distribution of water. It is not surprising that the tank irrigation system became a permanent feature in the dry zone landscape.

Mahakanumulla cascade system located in North Central Province is a branch type cascade and consists of 27 small tanks. Of all tanks 5 are located along the main valley. The total extend of paddy field under this cascade is approximately 324 ha and around 1600 families live under this cascade (Pannabokke et al., 2002). However, the equilibrium state of tank in relation to the water quality could be disrupted by the intensive agriculture practices and human activities with growing population. Accumulation of nutrient elements in tank water due to the added fertilizers, dung and urine of the large cattle population could degrade water

\footnotetext{
Department of Soil Science, Faculty of Agriculture, University of Peradeniya, Sri Lanka.

Corresponding author: geethikawijesundara@yahoo.com
} 
quality and brings in potential hazards to the human health (Young et al., 2010). Tank cascade system has very specific features and each and every component of the eco system was given due consideration. Recently, attention was only given to all macro land uses such as paddy land, settlement area, chena lands, tank beds etc. neglecting micro land uses such as Godawela, Iswatiya, Gasgommana, Perahana, Kattakaduwa, Thisbaba, Kiul ela etc. For instances, main duty of Gasgommana, Perahana and Godawela is to prevent entering upper catchment irrigation water and sediment directly to tank water. Those micro land uses act as physical barriers and silt trapping filters (Dharmasena, 2004). With the disappearance of most of features due to less attention, runoff water with sediment particles and plant nutrient elements directly enter to the tank water and degrade tank water quality and increase sedimentation. In this Mahakanumulla tank cascade system, no systematic work, however, has been carried out on water quality aspects particularly on the accumulation and fluctuation of plant nutrients and Heavy metal. Therefore the main objective of this research is to study the seasonal changes and spatial variations of the concentration of major plant nutrients viz. Nitrate $\left(\mathrm{NO}_{3}{ }^{-}\right)$and Phosphate $\left(\mathrm{PO}_{4}{ }^{3-}\right)$, Potassium $\left(\mathrm{K}^{+}\right)$and heavy metal Cadmium $\left(\mathrm{Cd}^{+2}\right)$ in water along the Mahakanumulla tank cascade in dry zone of Sri Lanka.

\section{MATERIALS AND METHODS}

Field work has been carried out in the Thirappane area. Main tanks from Mahakanumulla cascade, namely Mahakanumulla, Amanakkatuwa and Siwalagala were selected for this study (Fig. 1). Three sampling points from water channel along paddy fields under each tank were selected subsequent to a survey to represent the respective areas. Two sets of water samples were taken at monthly intervals from three tanks and from three selected locations of water canal along paddy track from February 2011 to January 2012. One set was filtered and acidified for metals analysis and few drops of chloroform were added for the other set. The chemical analysis the samples was conducted at the Department of Soil Science, University of Peradeniya. In all water samples, $\mathrm{NO}_{3}{ }^{-}$and $\mathrm{PO}_{4}{ }^{3-}$ were determined using Sodium Salicylate and Molybdate blue colorimetric procedures respectively. $\mathrm{K}^{+}$ determination was done using Flame Emission Spectrophotometer (FES). $\mathrm{Cd}^{+2}$ of water samples measured using Atomic adsorption spectrophotometer. The data were analyzed statistically with ANOVA and Turkey's Student zed Range test comparison.

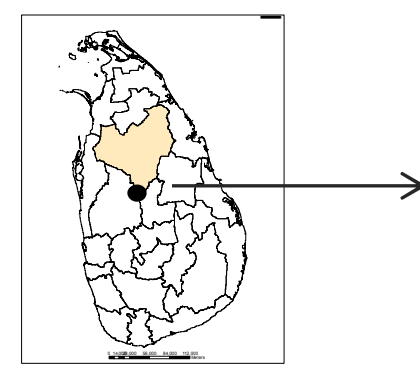

Fig. 1. Mahakanumulla tank cascade

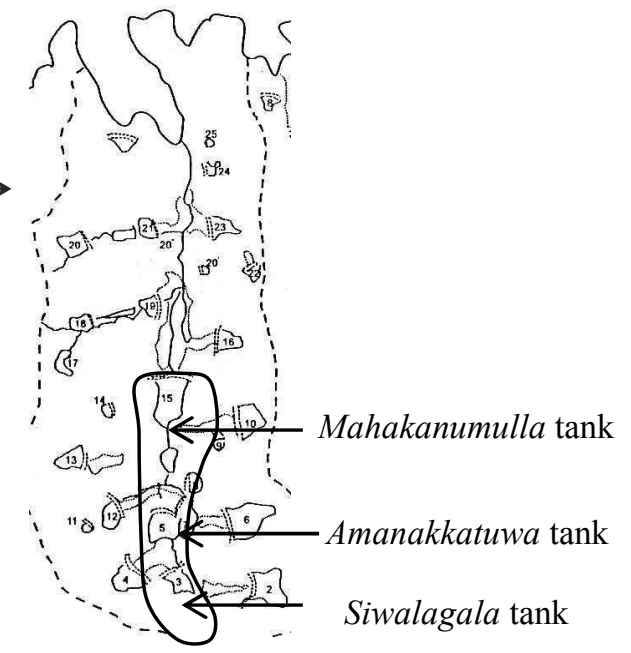




\section{RESULTS AND DISCUSSION}

The results of the concentrations of major plant nutrients ; $\mathrm{NO}_{3}{ }^{-}, \mathrm{PO}_{4}{ }^{3-}, \mathrm{K}^{+}$heavy metal $\mathrm{Cd}^{+2}$ in water samples of the Mahakanumulla cascade from February 2011 to January 2012 are given in Tables 1, 2, 3 and 4. According to the results, three major plant nutrients and $\mathrm{Cd}^{+2}$ showed statistically significant spatial and temporal variations over the study period (Fig: 2, 3, 4 and 5)

\section{Temporal and spatial variation of nitrate in the cascade}

In dry zone, there are two distinct cropping seasons namely Yala and Maha. Yala and Maha seasons fall in the months of May to September and October to March respectively. In the Yala season, land preparation for paddy cultivation is carried out in late April to early May and planting begins in early weeks of May. In this period, fertilizers are applied as basal and top dressings to the fields. Also application of excess amount of fertilizer resulted in enhancement of nutrient content in the surface runoff (Chun et al., 2003). It is reported that high quantity of sediment particles transfer via irrigation channel and finally end up with tank during the land preparation period. In this twelve months study period, $\mathrm{NO}_{3}{ }^{-}$varied from 2.17-4.87 $\mathrm{mgL}^{-1}$ and highest $\mathrm{NO}_{3}{ }^{-}$concentration was recorded during the rainy months of April, October and November comparatively to the drier months of July, August and September (Table 1). These high $\mathrm{NO}_{3}{ }^{-}$values observed during the months of April to May and October to November were also coincided with the fertilizer application period in rice cultivation of the area. Highest concentration of $\mathrm{NO}_{3}{ }^{-}$waters of three tanks was observed in months of April and May in Yala compared to the Maha season. Low nutrients concentration in the Maha period could be due to dilution effect caused by comparatively high volume of tank water during Maha season (Wijesundara et al., 2011a).

It was also found that the nutrients concentration of waters of these three tanks showed a bimodal pattern which was coincided with the bimodal rainfall of the dry zone (Wijesundara et al., 2011b;2011c). The concentrations of $\mathrm{NO}_{3}{ }^{-}$of the water samples collected from the three sampling points along the paddy track of the commanding area of Siwalagala and Amanakkatuwa tanks were also showed a statistically significant temporal variation and followed a bimodal pattern similar to the $\mathrm{NO}_{3}{ }^{-}$fluctuation in the waters of three tanks (Table 1 and Fig 2, 3). During Yala season, comparatively high $\mathrm{NO}_{3}{ }^{-}$level can be seen in irrigation water. Paddy fields are normally irrigated using tank water in yala season. In contrary to this in yala season, sufficient amount of rainfall occurs in Maha season and thereby irrigation issue is not much arisen. In the yala season, irrigation water circulates through whole paddy field and wash off many nutrients from the soil and finally move them to the next field. Therefore high concentration of $\mathrm{NO}_{3}{ }^{-}$could be observed during the yala season. 
Table 1. Nitrate $\left(\mathrm{mgL}^{-1}\right)$ movement through Mahakanumulla cascade - Feb 2011 -Jan 2012

\begin{tabular}{|c|c|c|c|c|c|c|c|c|c|c|c|c|}
\hline $\begin{array}{l}\text { Sampling } \\
\text { points }\end{array}$ & Feb & Mar & $\begin{array}{c}\text { Apri } \\
\text { I }\end{array}$ & May & June & July & Aug & Sep & Oct & Nov & Dec & Jan \\
\hline & & & & & & 2011 & & & & & & 2012 \\
\hline Siw & $\begin{array}{r}2.17^{\mathrm{g}} \\
\mathrm{E}\end{array}$ & $\begin{array}{r}2.54^{\mathrm{e}} \\
\mathrm{BC}\end{array}$ & $\begin{array}{r}2.88^{\mathrm{f}} \\
\mathrm{g} \\
\mathrm{A}\end{array}$ & $\begin{array}{r}2.53^{\mathrm{f}} \\
\mathrm{C}\end{array}$ & $\begin{array}{r}2.37^{\mathrm{g}} \\
\text { D }\end{array}$ & $\begin{array}{r}2.15^{\mathrm{g}} \\
\mathrm{E}\end{array}$ & $\begin{array}{r}2.16^{\mathrm{g}} \\
\mathrm{E}\end{array}$ & $\begin{array}{r}2.25^{\mathrm{e}} \\
\mathrm{E}\end{array}$ & $\begin{array}{r}2.84^{\mathrm{g}} \\
\mathrm{A}\end{array}$ & $\begin{array}{r}2.65^{\mathrm{h}} \\
B\end{array}$ & $\begin{array}{r}2.42^{f} \\
E\end{array}$ & $\begin{array}{r}2.15^{\mathrm{e}} \\
\mathrm{E}\end{array}$ \\
\hline field R1 & $\begin{array}{r}2.23^{f} \\
g \\
F\end{array}$ & $\begin{array}{r}2.51^{\mathrm{e}} \\
\mathrm{D}\end{array}$ & $\begin{array}{r}2.84 \\
\mathrm{~g} \\
\mathrm{~B}\end{array}$ & $\begin{array}{r}2.85^{\mathrm{e}} \\
B\end{array}$ & $\begin{array}{r}2.63^{\mathrm{f}} \\
B C\end{array}$ & $\begin{array}{r}2.49^{\mathrm{f}} \\
\mathrm{C}\end{array}$ & $\begin{array}{r}2.31^{\mathrm{f}} \\
{ }_{\mathrm{D}}\end{array}$ & $\begin{array}{r}2.35^{\mathrm{e}} \\
E F\end{array}$ & $\begin{array}{r}3.08^{\mathrm{f}} \\
\mathrm{E}\end{array}$ & $\begin{array}{r}2.92^{\mathrm{g}} \\
A\end{array}$ & $\begin{array}{r}2.56^{\mathrm{e}} \\
\mathrm{f} \\
\mathrm{B}\end{array}$ & $\begin{array}{r}2.31^{\mathrm{d}} \\
{ }_{C D}\end{array}$ \\
\hline field R2 & $\begin{array}{r}2.38 \\
\mathrm{~d} \\
\mathrm{G}\end{array}$ & $\begin{array}{r}2.67^{\mathrm{d}} \\
E\end{array}$ & $\begin{array}{r}2.94^{\mathrm{f}} \\
\mathrm{g} \\
\mathrm{D}\end{array}$ & $\begin{array}{r}3.57^{\mathrm{d}} \\
B\end{array}$ & $3.11^{\mathrm{e}}$ & $\begin{array}{r}2.91^{\mathrm{d}} \\
\mathrm{D}\end{array}$ & $\begin{array}{r}2.63^{\mathrm{bc}} \\
\mathrm{EF}\end{array}$ & $\begin{array}{r}2.60^{\mathrm{d}} \\
E F\end{array}$ & $\begin{array}{r}3.75^{\mathrm{d}} \\
\mathrm{e} \\
\mathrm{A}\end{array}$ & $\begin{array}{r}3.43^{\mathrm{f}} \\
B\end{array}$ & $\begin{array}{r}2.98^{\mathrm{b}} \\
\mathrm{CD}\end{array}$ & $\begin{array}{r}2.48^{\mathrm{c}} \\
G\end{array}$ \\
\hline field R3 & $\begin{array}{r}2.55 \\
\mathrm{~b} \\
\mathrm{G}\end{array}$ & $\begin{array}{r}2.93^{\mathrm{b}} \\
\mathrm{EF}\end{array}$ & $\begin{array}{r}3.45^{\mathrm{d}} \\
C D\end{array}$ & $\begin{array}{r}4.85^{\mathrm{b}} \\
\mathrm{A}\end{array}$ & $\begin{array}{r}3.56^{\mathrm{b}} \\
\mathrm{C}\end{array}$ & $\begin{array}{r}3.49^{\mathrm{a}} \\
C D\end{array}$ & $\begin{array}{r}2.84^{\mathrm{a}} \\
\mathrm{F}\end{array}$ & $\begin{array}{r}3.07^{\mathrm{b}} \\
\mathrm{E}\end{array}$ & $\begin{array}{r}4.49^{\mathrm{a}} \\
\mathrm{B}\end{array}$ & $\begin{array}{r}4.35^{\mathrm{a}} \\
\mathrm{b} \\
\mathrm{B}\end{array}$ & $\begin{array}{r}3.37^{\mathrm{a}} \\
\mathrm{D}\end{array}$ & $2.62^{\mathrm{b}}$ \\
\hline $\begin{array}{l}\text { Amana } \\
\text { tank }\end{array}$ & $\begin{array}{r}2.26^{\mathrm{e}} \\
\mathrm{f} \\
\mathrm{G}\end{array}$ & $\begin{array}{r}2.66^{\mathrm{d}} \\
E F\end{array}$ & $\begin{array}{r}3.01_{\mathrm{f}}^{\mathrm{e}} \\
\mathrm{CD}\end{array}$ & $\begin{array}{r}4.56^{\mathrm{c}} \\
\mathrm{A}\end{array}$ & $\begin{array}{r}3.14^{\mathrm{e}} \\
\end{array}$ & $\begin{array}{r}3.16^{\mathrm{c}} \\
\mathrm{C}\end{array}$ & $\begin{array}{r}2.44^{\mathrm{e}} \\
F G\end{array}$ & $\begin{array}{r}2.79^{\mathrm{c}} \\
\mathrm{DE}\end{array}$ & $\begin{array}{r}3.99^{\mathrm{b}} \\
\mathrm{c} \\
\mathrm{B}\end{array}$ & $\begin{array}{r}3.87^{\mathrm{d}} \\
B\end{array}$ & $\begin{array}{r}2.64^{\mathrm{d}} \\
\mathrm{e} \\
\mathrm{EF}\end{array}$ & $\begin{array}{r}2.39^{\mathrm{c}} \\
\mathrm{d} \\
\mathrm{G}\end{array}$ \\
\hline field RI & $\begin{array}{r}2.29^{\mathrm{e}} \\
{ }_{\mathrm{I}}\end{array}$ & $\begin{array}{r}2.80^{\mathrm{c}} \\
\mathrm{F}\end{array}$ & $\begin{array}{r}3.17^{\mathrm{e}} \\
E\end{array}$ & $\begin{array}{r}4.69^{\mathrm{b}} \\
\mathrm{c} \\
\mathrm{A}\end{array}$ & $\begin{array}{r}3.25^{\mathrm{d}} \\
\mathrm{e} \\
\mathrm{D}\end{array}$ & $\begin{array}{r}3.17^{\mathrm{c}} \\
\mathrm{E}\end{array}$ & $\begin{array}{r}2.54^{\mathrm{cd}} \\
\mathrm{e} \\
\mathrm{G}\end{array}$ & $\begin{array}{r}2.84^{\mathrm{c}} \\
F\end{array}$ & $\begin{array}{r}3.88^{\mathrm{c}} \\
\mathrm{d} \\
\mathrm{C}\end{array}$ & $\begin{array}{r}4.08^{\mathrm{c}} \\
B\end{array}$ & $\begin{array}{r}2.78^{\mathrm{c}} \\
\mathrm{d} \\
\mathrm{F}\end{array}$ & $\begin{array}{r}2.44^{\mathrm{c}} \\
\mathrm{H}\end{array}$ \\
\hline field R2 & $2.44^{\mathrm{c}}$ & $\begin{array}{r}2.93^{b} \\
G\end{array}$ & $\begin{array}{r}3.71^{\mathrm{c}} \\
\mathrm{D}\end{array}$ & $\begin{array}{r}4.87^{\mathrm{b}} \\
\mathrm{A}\end{array}$ & $\begin{array}{r}3.47^{\mathrm{b}} \\
\mathrm{c} \\
\mathrm{E}\end{array}$ & $\begin{array}{r}3.30^{\mathrm{b}} \\
\mathrm{F}\end{array}$ & $\begin{array}{r}2.57^{\mathrm{bc}} \\
\mathrm{d} \\
\mathrm{H}\end{array}$ & $\begin{array}{r}2.99^{\mathrm{b}} \\
\mathrm{G}\end{array}$ & $\begin{array}{r}4.10^{\mathrm{b}} \\
\mathrm{C}\end{array}$ & $\begin{array}{r}4.24^{\mathrm{b}} \\
\mathrm{c} \\
\mathrm{B}\end{array}$ & $\begin{array}{r}2.91_{\mathrm{c}}^{\mathrm{b}} \\
\mathrm{G}\end{array}$ & $\begin{array}{r}2.60^{\mathrm{b}} \\
\mathrm{H}\end{array}$ \\
\hline field R3 & $\begin{array}{r}2.66 \\
\mathrm{a} \\
\mathrm{H}\end{array}$ & $\begin{array}{r}3.15 \\
\mathrm{a} \\
\mathrm{G}\end{array}$ & $\begin{array}{r}4.56^{\mathrm{a}} \\
\mathrm{B}\end{array}$ & $\begin{array}{r}5.22^{\mathrm{a}} \\
\mathrm{A}\end{array}$ & $\begin{array}{r}3.78^{\mathrm{a}} \\
D\end{array}$ & $\begin{array}{r}3.30^{\mathrm{b}} \\
\mathrm{E}\end{array}$ & $\begin{array}{r}2.65^{b} \\
H\end{array}$ & $\begin{array}{r}3.39^{\mathrm{a}} \\
E\end{array}$ & $\begin{array}{r}4.40^{\mathrm{a}} \\
\mathrm{C}\end{array}$ & $\begin{array}{r}4.46^{\mathrm{a}} \\
\mathrm{BC}\end{array}$ & $\begin{array}{r}3.28^{\mathrm{a}} \\
\mathrm{E}\end{array}$ & $\begin{array}{r}2.84^{\mathrm{a}} \\
\mathrm{G}\end{array}$ \\
\hline $\begin{array}{l}\text { Maha } \\
\text { tank }\end{array}$ & $\begin{array}{r}2.29^{\mathrm{e}} \\
\mathrm{H}\end{array}$ & $\begin{array}{r}2.54^{\mathrm{e}} \\
\mathrm{GH}\end{array}$ & $\begin{array}{r}4.27^{\mathrm{b}} \\
\text { B }\end{array}$ & $\begin{array}{r}4.77^{\mathrm{b}} \\
\mathrm{c} \\
\mathrm{A}\end{array}$ & $\begin{array}{r}3.35^{\mathrm{c}} \\
\mathrm{d} \\
\mathrm{D}\end{array}$ & $\begin{array}{r}2.80^{\mathrm{e}} \\
\mathrm{EF}\end{array}$ & $\begin{array}{r}2.50^{\mathrm{de}} \\
\mathrm{H}\end{array}$ & $\begin{array}{r}2.84^{\mathrm{c}} \\
\mathrm{E}\end{array}$ & $\begin{array}{r}3.70^{\mathrm{e}} \\
\mathrm{C}\end{array}$ & $\begin{array}{r}3.66^{\mathrm{e}} \\
{ }_{C}\end{array}$ & $\begin{array}{r}2.66^{\mathrm{d}} \\
\mathrm{e} \\
\mathrm{G}\end{array}$ & $\begin{array}{r}2.39^{\mathrm{c}} \\
\mathrm{d} \\
\mathrm{HI}\end{array}$ \\
\hline
\end{tabular}

-Means with same letters are not significantly different. Siw tank -Siwalagala tank, Amana tank-Amanakkatuwa tank, Maha tank-Mahakanumulla tank. (Upper case letters - temporal variation, Lower case letters- spatial variation).

Spatial distribution of $\mathrm{NO}_{3}{ }^{-}$concentration in the water of three sampling locations of each paddy track showed significant increasing trend from first point to third sampling point of the paddy field (Siwalagala field $\mathrm{R}_{3}$, Amanakkatuwa field $\mathrm{R}_{3}$ ) in every months. For an example, in paddy track of Siwalagala tank inthe month of April, $\mathrm{NO}_{3}{ }^{-}$concentration of 2.84 $\mathrm{mgL}^{-1}$ in field R1 has been increased to $3.45 \mathrm{mgL}^{-1}$ in field $\mathrm{R} 3$ while field $\mathrm{R} 1$ of Amanakkatuwa tank $\mathrm{NO}_{3}{ }^{-}$concentration of $3.17 \mathrm{mgL}^{-1}$ in field $\mathrm{R} 1$ has been increased to 4.56 $\mathrm{mgL}^{-1}$ in the field $\mathrm{R} 3$ (Table 1).However, there was a little reduction of $\mathrm{NO}_{3}{ }^{-}$concentration when water transfers through tank thaulla area. Tank thaulla is acting as filter for most of plant nutrients and sediments. However, there was a significant steady increase of $\mathrm{NO}_{3}{ }^{-}$ concentration from uppermost Siwalagala tank to Amanakkatuwa tank (middle) and to the lowermost Mahakanumulla tank. For an example in the month of April, $\mathrm{NO}_{3}{ }^{-}$concentration of $2.88 \mathrm{mgL}^{-1}$ in Siwalagala tank increased to $3.01 \mathrm{mgL}^{-1}$ in Amanakkatuwa tank and to 4.27 $\mathrm{mgL}^{-1}$ in Mahakanumulla tank (Table 1 and Fig 4). 


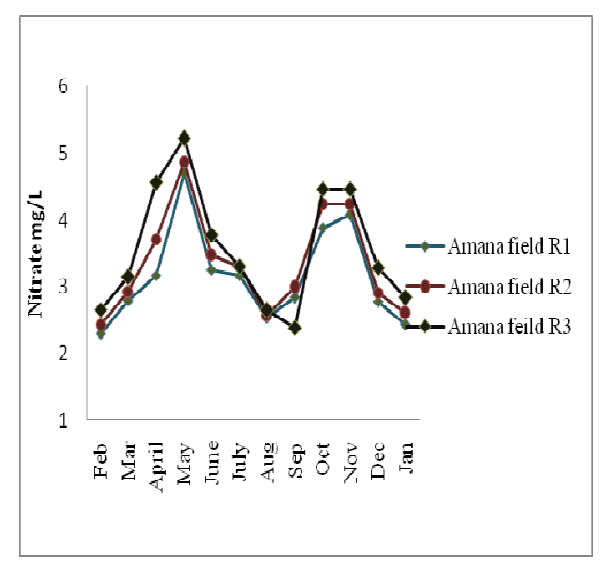

Fig. 2. Temporal variation of $\mathrm{NO}_{3}^{-}$ Amanakkatuwa fields

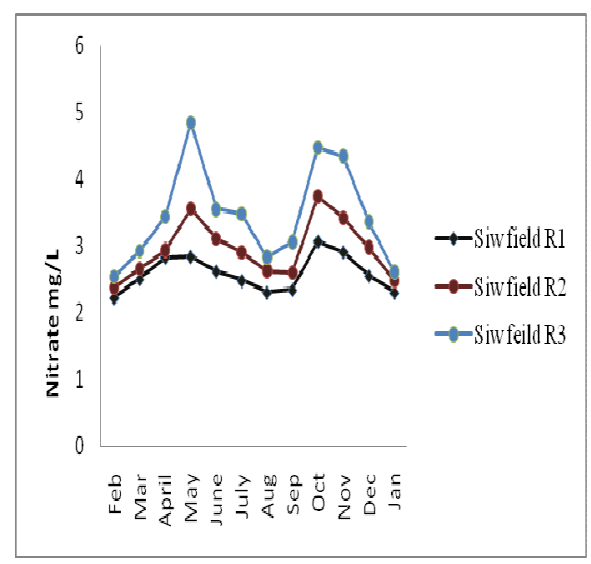

Fig. 3. Temporal variation of $\mathrm{NO}_{3}^{-}$concentration in concentration in Siwalagala paddy fields

This clearly indicates when water moves from upper to lower tanks of the cascade system there is a trend of accumulation of certain elements in the waters of lower tanks. However, the $\mathrm{NO}_{3}{ }^{-}$concentration didn't exceed the permissible level of $10 \mathrm{mgL}^{-1}$ (WHO, 2004) for drinking and irrigation water. The $\mathrm{NO}_{3}{ }^{-}$values observed in the surface water indicate the low $\mathrm{NO}_{3}{ }^{-}$accumulation rate, despite high application rates of nitrate as urea fertilizer as in the recent catchment cultivated areas. Along the bank of irrigation canals, heavy growth of plants are present even during dry period, this indicates that those may absorb nutrients from the water, which carry nutrients from cultivated field. This process may also reduce the nutrient level in water (Hill 1996; Lamontagne et al., 2001).

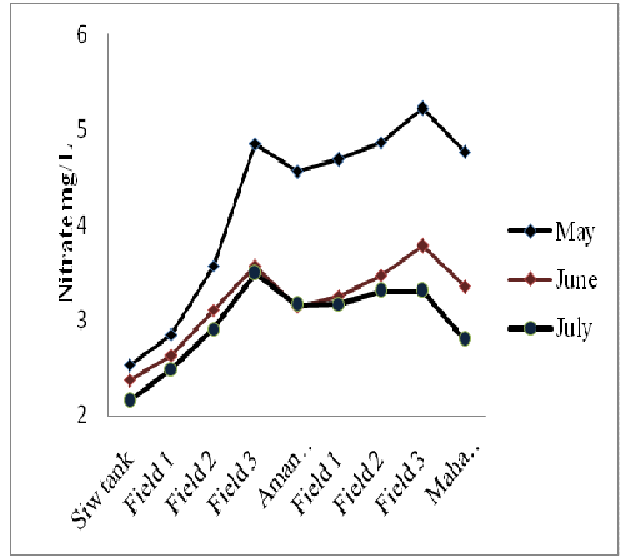

Fig. 4. Spatial variation of $\mathrm{NO}_{3}{ }^{-}$concentration Mahakanumulla cascade

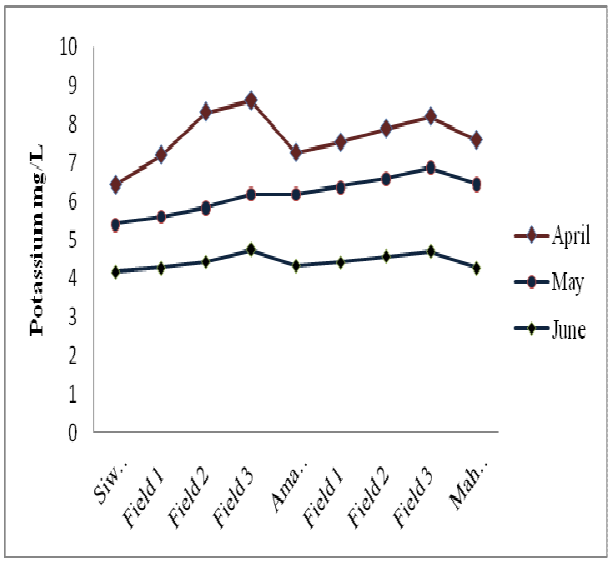

Fig. 5. Spatial variation of $\mathrm{K}^{+}$in concentration along Mahakanumulla cascade 
Temporal and spatial variation of phosphate in the cascade

Table 2. Phosphate $\left(\mathrm{mgL}^{-1}\right)$ movement through Mahakanumulla cascade - Feb 2011 Jan 2012

\begin{tabular}{|c|c|c|c|c|c|c|c|c|c|c|c|c|}
\hline \multirow{2}{*}{$\begin{array}{l}\text { Sampling } \\
\text { points }\end{array}$} & Feb & Mar & April & May & June & July & Aug & Sep & Oct & Nov & Dec & Jan \\
\hline & \multicolumn{11}{|c|}{2011} & 2012 \\
\hline Siw tank & $\begin{array}{l}0.01^{\mathrm{cd}} \\
\mathrm{CDEF}\end{array}$ & $\begin{array}{c}0.01^{b} \\
C D E\end{array}$ & $0.02^{\mathrm{e}}$ & $\begin{array}{c}0.01^{\mathrm{eB}} \\
\mathrm{BCD}\end{array}$ & $\begin{array}{c}0.009^{\mathrm{dD}} \\
\text { DEF }\end{array}$ & $\underset{\mathrm{E}}{0.007^{\mathrm{c}}}$ & $\begin{array}{c}0.008^{\mathrm{e}} \\
\mathrm{EF}\end{array}$ & $\begin{array}{l}0.01^{\mathrm{cdc}} \\
\end{array}$ & $0.01^{\mathrm{d}}{ }^{\mathrm{d}}$ & $0.02^{b}$ & $\begin{array}{c}0.02^{\mathrm{ab}} \\
\mathrm{B}\end{array}$ & $\begin{array}{c}0.01^{\mathrm{d}} \\
\mathrm{DEF}\end{array}$ \\
\hline field R1 & $\frac{0.02^{\mathrm{bc}}}{\mathrm{BC}}$ & $\frac{0.02^{\mathrm{ab}}}{\mathrm{bC}}$ & $0.03^{\mathrm{d}}$ & ${ }^{0.01^{\mathrm{C}}}$ & $\underset{\mathrm{DE}}{0.01^{\mathrm{cd}}}$ & $\begin{array}{c}0.009^{\mathrm{c}} \\
\mathrm{DE}\end{array}$ & $\underset{E}{0.008^{\mathrm{de}}}$ & $0.01^{\mathrm{bD}}$ & $\begin{array}{c}0.02^{\mathrm{C}} \\
\mathrm{BC}\end{array}$ & $0.02^{\mathrm{b}}$ & $\frac{0.01^{\mathrm{bc}}}{\mathrm{CDE}}$ & $\begin{array}{c}0.01^{\mathrm{bc}} \\
\mathrm{CDE}\end{array}$ \\
\hline field R2 & $\frac{0.02^{\mathrm{ab}}}{\mathrm{ab}}$ & $\frac{0.03^{\mathrm{ab}}}{}$ & $\frac{0.04^{\mathrm{bc}}}{\mathrm{A}}$ & $0.03^{\mathrm{d}}$ & $\underset{\mathrm{EF}}{0.01^{\mathrm{bcd}}}$ & $0.01^{\mathrm{b}}$ & $\frac{0.01^{\mathrm{de}}}{\mathrm{F}}$ & $\underset{\mathrm{E}}{0.02^{\mathrm{ab}}}$ & $\underset{\mathrm{DE}}{0.02^{\mathrm{bc}}}$ & $\frac{0.02^{\mathrm{b}}}{\mathrm{BC}}$ & $\underset{\mathrm{E}}{0.01^{\mathrm{ab}}}$ & $\underset{\mathrm{E}}{0.02^{\mathrm{ab}}}$ \\
\hline field R3 & $0.03^{\mathrm{a}}$ & $0.04^{\mathrm{ab}}$ & $0.05^{\mathrm{a}}$ & $\frac{0.04^{\mathrm{cd}}}{\mathrm{B}}$ & $\underset{\mathrm{E}}{0.02^{\mathrm{b}}}$ & $0.02^{\mathrm{a}}$ & $\frac{0.01^{\mathrm{cd}}}{\mathrm{F}}$ & $\underset{\mathrm{E}}{0.02^{\mathrm{ab}}}$ & $\begin{array}{c}0.02^{\mathrm{abc}} \\
\mathrm{DE}^{\mathrm{abc}}\end{array}$ & $0.02^{\mathrm{b}}$ & $\underset{\mathrm{DE}}{0.02^{\mathrm{a}}}$ & $\underset{\mathrm{DE}}{0.02^{\mathrm{a}}}$ \\
\hline Amana tank & $\underset{\mathrm{CDE}}{0.01^{\mathrm{cd}}}$ & $\underset{\mathrm{CDE}}{0.01^{\mathrm{b}}}$ & $0.04^{\mathrm{b}}$ & $\underset{B}{0.03^{d}}$ & $\frac{0.01^{\mathrm{bc}}}{\mathrm{CD}^{-}}$ & $\underset{\mathrm{E}}{0.01^{\mathrm{bc}}}$ & $\underset{\mathrm{E}}{0.01^{\mathrm{cde}}}$ & $\underset{D E}{0.01^{\mathrm{de}}}$ & $0.02^{\mathrm{C}}$ & $0.03^{\mathrm{a}}$ & $\frac{0.01^{\mathrm{bc}}}{\mathrm{CDE}}$ & $\underset{E}{0.01^{d}}$ \\
\hline field R1 & $\underset{\mathrm{EF}}{0.01^{\mathrm{d}}}$ & $0.02^{\mathrm{ab}}$ & $\underset{B}{0.03^{c d}}$ & $\underset{\mathrm{A}}{0.04^{\mathrm{c}}}$ & $0.03^{\mathrm{a}}$ & $\underset{\mathrm{F}}{0.009^{\mathrm{c}}}$ & $0.01^{\mathrm{bc}}$ & $\underset{D E}{0.01^{\mathrm{bc}}}$ & $\underset{\mathrm{CD}}{0.02^{\mathrm{bc}}}$ & $\frac{0.02^{\mathrm{b}}}{\mathrm{C}}$ & $\underset{\mathrm{EF}}{0.01^{\mathrm{C}}}$ & $\begin{array}{c}0.009 \\
\mathrm{~d} \\
\mathrm{~F}\end{array}$ \\
\hline field R2 & $\underset{\mathrm{EF}}{0.01^{\mathrm{cd}}}$ & $\underset{C}{0.03^{\mathrm{ab}}}$ & $\underset{B}{0.04^{b}}$ & $\underset{\mathrm{A}}{0.05^{\mathrm{b}}}$ & $\underset{B}{0.04^{\mathrm{a}}}$ & $\underset{\mathrm{F}}{0.01^{\mathrm{bc}}}$ & $\underset{\mathrm{DEF}}{0.01^{\mathrm{a}}}$ & $\underset{\mathrm{CDE}}{0.02^{\mathrm{ab}}}$ & $\underset{\mathrm{DE}}{0.02^{\mathrm{ab}}}$ & $\frac{0.02^{\mathrm{b}}}{\mathrm{CD}}$ & $\underset{\mathrm{F}}{0.01^{\mathrm{c}}}$ & $\underset{\mathrm{EF}}{0.01^{\mathrm{bc}}}$ \\
\hline field R3 & $\underset{\mathrm{E}}{0.02^{\mathrm{ab}}}$ & $0.04^{\mathrm{ab}}$ & $0.05^{\mathrm{a}}$ & $\frac{0.07^{\mathrm{a}}}{\mathrm{A}}$ & $\frac{0.03^{\mathrm{a}}}{\mathrm{C}}$ & $\underset{\mathrm{FG}}{0.01^{\mathrm{b}}}$ & $\underset{\mathrm{FG}}{0.01^{\mathrm{ab}}}$ & $\underset{E F}{0.02^{\mathrm{a}}}$ & $\underset{\mathrm{E}}{0.02^{\mathrm{a}}}$ & $\begin{array}{c}0.02^{\mathrm{b}} \\
\mathrm{DE}\end{array}$ & $\underset{\mathrm{G}}{0.01^{\mathrm{bc}}}$ & $\frac{0.01^{\mathrm{bc}}}{\mathrm{G}}$ \\
\hline Maha tank & $\underset{B}{0.01^{\mathrm{cd}}}$ & $\underset{\mathrm{A}}{0.07^{\mathrm{a}}}$ & $\underset{\mathrm{B}}{0.02^{\mathrm{de}}}$ & $\underset{\mathrm{B}}{0.01^{\mathrm{e}}}$ & $\underset{\mathrm{B}}{0.01^{\mathrm{cd}}}$ & $\underset{\mathrm{B}}{0.01^{\mathrm{bc}}}$ & $\underset{B}{0.01^{\mathrm{de}}}$ & $\underset{\mathrm{B}}{0.01^{\mathrm{e}}}$ & $\frac{0.02^{\mathrm{abc}}}{\mathrm{ab}}$ & $\underset{\mathrm{B}}{0.01^{\mathrm{c}}}$ & $\underset{B}{0.01^{\mathrm{C}}}$ & $\underset{B}{0.01^{d}}$ \\
\hline
\end{tabular}

-Means with same letters are not significantly different. Siw tank -Siwalagala tank, Amana tank-Amanakkatuwa tank, Maha tank-Mahakanumulla tank. (Upper case letters - temporal variation, Lower case letters- spatial variation).

Concentration of $\mathrm{PO}_{4}{ }^{3-}$ of the water of three tanks of the Mahakanumulla cascade and three sampling points of the paddy tracks of Siwalagala and Amanakkatuwa tanks was ranged from 0.009 to $0.05 \mathrm{mgL}^{-1}$ and also showed a significant spatial and temporal variation during the study period (Table 02). The temporal distribution of $\mathrm{PO}_{4}{ }^{3-}$ is concerned, almost similar to $\mathrm{NO}_{3}{ }^{-}, \mathrm{PO}_{4}{ }^{3-}$ concentration of waters of Siwalagala, Amanakkatuwa and Mahakanumulla tanks were high in the months of April and May of Yala season while relatively lower values were recorded for the Maha season. Similar trend was also observed with the $\mathrm{PO}_{4}{ }^{3-}$ concentration of water samples collected from the three sampling points along the paddy track of the commanding area of Siwalagala and Amanakkatuwa tanks.Collectively $\mathrm{PO}_{4}{ }^{3-}$ concentrations of all water samples were showed a significant temporal variation and followed a bimodal pattern which was coincided with the bimodal rainfall of the dry zone. $\mathrm{PO}_{4}{ }^{3-}$ concentration in the waters of Siwalagala, Amanakkatuwa, Mahakanumulla tanks and three sampling locations of each paddy track along the cascade showed significant spatial distribution and indicated an increasing trend from first point to third sampling point of the paddy field ( Siwalagala field $\mathrm{R}_{3}$, Amanakkatuwa field $\mathrm{R}_{3}$ ). For an example, in paddy track of Siwalagala tank in the month of April, $\mathrm{PO}_{4}{ }^{3-}$ concentration of $0.03 \mathrm{mgL}^{-1}$ in field $\mathrm{R} 1$ has been increased to $0.05 \mathrm{mgL}^{-1}$ in field $\mathrm{R} 3$ while field R1 of Amanakkatuwa tank $\mathrm{PO}_{4}^{3-}$ concentration of $0.03 \mathrm{mgL}^{-1}$ in field $\mathrm{R} 1$ has been increased to $0.05 \mathrm{mgL}^{-1}$ in the field R3( Table 2). Hence, during the study period, highest $\mathrm{PO}_{4}{ }^{3-}$ values were detected at lower position of paddy fields under each tank. This may be attributed to surface runoff during land preparation removing a considerable quantity of finer soil particles along with cattle dung and fertilizers from surrounding catchment areas. $\mathrm{PO}_{4}{ }^{3-}$ transport has found similar pattern with $\mathrm{NO}_{3}^{-}$, where the lowest content of $\mathrm{PO}_{4}^{3-}\left(0.02 \mathrm{mgL}^{-1}\right.$ in Siwalagala field R3) found within the maturity period of paddy (June, July) and the highest $\left(0.05 \mathrm{mgL}^{-1}\right.$ in Siwalagala field R3)after the chemical fertilizer application (Yala season - April to May, Maha season October to November)(Table 2). After chemical fertilizer application, $\mathrm{PO}_{4}{ }^{3-}$ concentration increased amazingly and thereafter decreased gradually (May and June). The rate of $\mathrm{PO}_{4}{ }^{3-}$ movement may also be influenced by land preparation. During the drier months where there 
is no continuous water flow between each field and $\mathrm{PO}_{4}{ }^{3-}$ concentration remained in low concentrations (August, September). $\mathrm{PO}_{4}{ }^{3-}$ is one of the major macro nutrients which is responsible for the eutrophication of open water bodies. According to the Young et al. (2010), in some tank waters showed extremely higher values $\left(1.0-2.4 \mathrm{mgL}^{-1}\right)$. But in this cascade system, none of the water samples exceeded the $\mathrm{PO}_{4}{ }^{3-}$ level beyond the WHO detection level for drinking and irrigation water $\left(2 \mathrm{mgL}^{-1}\right)$.

\section{Temporal and spatial variation of potassium in the cascade}

$\mathrm{K}^{+}$content in surface water varies significantly with the season. Fairly high $\mathrm{K}^{+}$concentration was detected in surface water falling within the range of $2.14-8.61 \mathrm{mgL}^{-1}$, where the permissible level is $2 \mathrm{mgL}^{-1}$ according to WHO standards (Table 3). Similar to the $\mathrm{NO}_{3}{ }^{-}$and $\mathrm{PO}_{4}{ }^{3-}$, concentration of $\mathrm{K}^{+}$in the water of Siwalagala, Amanakkatuwa, Mahakanumulla tanks and three sampling locations of each paddy track along the cascade showed a significant statistical spatial and temporal variation during the study period (Table 3 ). $\mathrm{K}^{+}$concentration in surface water was higher in the months of April and May within the Yala season while relatively low values were recorded for the Maha season. Such elevated contents of $\mathrm{K}^{+}$have been observed during the seed sowing period by Gunawardana and Kumuduni (1980) as well.

Table 3. Potassium $\left(\mathrm{mgL}^{-1}\right)$ movement through Mahakanumulla cascade - Feb 2011 Jan 2012

\begin{tabular}{|c|c|c|c|c|c|c|c|c|c|c|c|c|}
\hline \multirow{2}{*}{$\begin{array}{l}\text { Sampling } \\
\text { points }\end{array}$} & Feb & Mar & April & May & June & July & Aug & Sep & Oct & Nov & Dec & Jan \\
\hline & \multicolumn{11}{|c|}{2011} & 2012 \\
\hline Siw tank & $\underset{\mathrm{F}}{2.66^{\mathrm{g}}}$ & $\underset{\mathrm{E}}{3.25^{\mathrm{e}}}$ & $6.43^{f}$ & $5.41^{\mathrm{g}}$ & $\underset{D}{4.17^{f}}$ & $2.47^{\mathrm{de}}$ & $\underset{H}{2.17^{d}}$ & $3.26^{\mathrm{f}}$ & $\underset{\mathrm{C}}{4.65^{f}}$ & $\underset{B}{5.26^{\mathrm{g}}}$ & $\underset{E}{3.17^{c}}$ & $\underset{\mathrm{H}}{2.23^{\mathrm{f}}}$ \\
\hline field R1 & $\underset{\mathrm{H}}{2.69^{\mathrm{fg}}}$ & $3.39^{\mathrm{de}}$ & $7.20^{\mathrm{e}}$ & $\underset{B}{5.60^{f}}$ & $\underset{\mathrm{E}}{4.2 \mathrm{~F}^{\mathrm{ef}}}$ & $\underset{\mathrm{H}}{2.61^{\mathrm{cd}}}$ & $2.32^{\mathrm{c}}$ & $3.40^{\mathrm{ef}}$ & $\underset{\mathrm{D}}{4.85^{\mathrm{de}}}$ & $5.42^{\text {ef }}$ & $3.27^{\mathrm{d}}$ & $2.34^{\mathrm{ef}}$ \\
\hline field R2 & $2.83^{\text {ef }}$ & $3.48^{\mathrm{de}}$ & $8.31^{b}$ & $\underset{B}{5.83^{\mathrm{e}}}$ & $4.43^{\mathrm{c}}$ & $2.78^{b}$ & $\underset{\mathrm{H}}{2.49^{\mathrm{b}}}$ & $3.52^{\text {cde }}$ & $\underset{\mathrm{D}}{5.06^{\mathrm{c}}}$ & $5.59^{\mathrm{cd}}$ & $3.48^{\mathrm{c}}$ & $\underset{\mathrm{H}}{2.48^{\mathrm{dc}}}$ \\
\hline field R3 & $\underset{\mathrm{G}}{2.97^{\mathrm{de}}}$ & $3.76^{\mathrm{c}}$ & $\underset{\mathrm{A}}{8.61^{\mathrm{a}}}$ & $\underset{B}{6.19^{d}}$ & $\underset{\mathrm{E}}{4.75^{\mathrm{a}}}$ & $3.11^{\mathrm{a}}$ & $\underset{\mathrm{H}}{2.63^{\mathrm{a}}}$ & ${ }_{\mathrm{F}}^{3.69^{\mathrm{bc}}}$ & $\underset{\mathrm{D}}{5.29^{\mathrm{b}}}$ & $\underset{\mathrm{C}}{5.79^{\mathrm{b}}}$ & $\underset{F}{3.66^{b}}$ & $\underset{\mathrm{H}}{2.68^{\mathrm{c}}}$ \\
\hline Amana tank & $\underset{\mathrm{H}}{2.82^{\mathrm{f}}}$ & $\frac{3.56^{\mathrm{cd}}}{\mathrm{F}}$ & $\underset{\mathrm{A}}{7.26^{\mathrm{e}}}$ & $\underset{B}{6.19^{d}}$ & $\underset{\mathrm{E}}{4.33^{\mathrm{de}}}$ & $2.28^{\mathrm{fg}}$ & $\underset{\mathrm{J}}{2.17^{\mathrm{d}}}$ & $3.44^{\mathrm{de}}$ & $\underset{\mathrm{D}}{4.65^{\mathrm{f}}}$ & $\underset{\mathrm{C}}{5.37^{\mathrm{fg}}}$ & $3.31^{d}$ & $\underset{1}{2.51^{\mathrm{d}}}$ \\
\hline field R1 & $3.11_{\mathrm{H}}^{\mathrm{cd}}$ & $\underset{\mathrm{F}}{3.80^{\mathrm{c}}}$ & $\underset{A}{7.53^{d}}$ & $\underset{B}{6.37^{c}}$ & $\underset{\mathrm{E}}{4.41^{\mathrm{cd}}}$ & $2.39^{\text {ef }}$ & $\underset{\mathrm{J}}{2.32^{\mathrm{c}}}$ & $\underset{G}{3.60^{\text {cd }}}$ & $\underset{\mathrm{D}}{4.81^{\mathrm{e}}}$ & $\begin{array}{c}5.50^{\mathrm{de}} \\
\end{array}$ & $3.51^{\mathrm{c}}$ & $\underset{1}{2.71^{c}}$ \\
\hline field R2 & $3.53^{b}$ & $\underset{\mathrm{F}}{4.22^{\mathrm{b}}}$ & $\underset{\mathrm{A}}{7.88^{\mathrm{c}}}$ & $\underset{B}{6.58^{b}}$ & $\underset{E}{4.57^{b}}$ & $2.55^{\mathrm{cd}}$ & $2.41^{b}$ & $3.80^{\mathrm{b}}$ & $\underset{D}{4.97^{\mathrm{cd}}}$ & $\underset{\mathrm{C}}{5.67^{\mathrm{bc}}}$ & $3.69^{b}$ & $\underset{1}{2.91^{\mathrm{b}}}$ \\
\hline field R3 & $3.92^{\mathrm{a}}$ & $\underset{\mathrm{E}}{4.70^{\mathrm{a}}}$ & $8.20^{b}$ & $\underset{B}{6.87^{a}}$ & $\underset{\mathrm{E}}{4.70^{\mathrm{a}}}$ & $2.66^{\mathrm{bc}}$ & $2.59^{\mathrm{a}}$ & $\underset{\mathrm{F}}{4.09^{\mathrm{a}}}$ & $\underset{\mathrm{D}}{5.25^{\mathrm{b}}}$ & $5.93^{\mathrm{a}}$ & $3.85^{\mathrm{a}}$ & ${ }_{\mathrm{H}}^{3.24^{\mathrm{a}}}$ \\
\hline Maha tank & $3.21^{\mathrm{c}}$ & $\underset{\mathrm{D}}{3.76^{\mathrm{c}}}$ & $\underset{A}{7.59^{d}}$ & $\underset{\mathrm{B}}{6.45^{\mathrm{bc}}}$ & $\underset{\mathrm{C}}{4.27^{\mathrm{e}}}$ & $\underset{1}{2.19^{g}}$ & $\underset{1}{2.14^{\mathrm{d}}}$ & $3.48^{\mathrm{de}}$ & $\underset{B}{6.30^{a}}$ & $\underset{\mathrm{C}}{4.48^{\mathrm{h}}}$ & $\underset{G}{2.83^{f}}$ & $\underset{\mathrm{H}}{2.58^{\mathrm{cd}}}$ \\
\hline
\end{tabular}

-Means with same letters are not significantly different. Siw tank -Siwalagala tank, Amana tank-Amanakkatuwa tank, Maha tank-Mahakanumulla tank. (Upper case letters - temporal variation, Lower case letters- spatial variation).

Similar to other nutrients, $\mathrm{K}^{+}$concentration also showed an increasing trend while nutrient moving through paddy fields and highest values were observed in third sampling location. The recommended $\mathrm{K}$ fertilizer for a $5 \mathrm{t} / \mathrm{ha}$ rice crop in the low country dry zone is only $38 \mathrm{~kg}$ $\mathrm{ha}^{-1}$. Runoff water and sediment transport with water may bring this elevated $\mathrm{K}^{+}$ concentration in the lower part of the paddy field from the applied $\mathrm{K}$ fertilizers and the accumulated cow dung and other organic residues in the thaulla and commanding area of the tanks. In general, surface waters in Sri Lanka are rich in $\mathrm{Na}^{+}, \mathrm{Ca}^{+2}$ and $\mathrm{Mg}^{+2}$. But the $\mathrm{K}^{+}$ concentration is in low level (Dissanayaka et al., 1982). 


\section{Temporal and spatial variation of cadmium in the cascade}

Concentration of $\mathrm{Cd}^{+2}$ of the water of three tanks of the Mahakanumulla cascade also showed a significant spatial and temporal variation during the study period (Table 4) and generally falls in a very narrow range $\left(0.09-0.33 \mathrm{mgL}^{-1}\right)$. The permissible level of $\mathrm{Cd}^{+2}$ in drinking water is less than $0.003 \mathrm{mgL}^{-1}$ according to the WHO standard (WHO, 2004). Almost all water samples showed higher values than the permissible level. Almost similar to the major plant nutrients discussed above, $\mathrm{Cd}^{+2}$ concentration in tank water was elevated in the months of April and May in Yala season while relatively lower values were recorded for the Maha season. Though the other major nutrients (N, P, and $\mathrm{K}$ ) added as chemical fertilizer, $\mathrm{Cd}^{+2}$ is not added for any field as it has not any beneficial effect on crop life. But with the chemical fertilizers such as triple super phosphate significant amount of $\mathrm{Cd}^{+2}$ could be added to the soil (McLaughlin et al., 1996). Average concentration of Cadmium in triple super phosphate sold in state of Califonia was $100 \mathrm{mg} / \mathrm{kg}$, whereas those in soft-phosphate rock were $130 \mathrm{mg} / \mathrm{kg}$ (California Department of Agriculture, 1998).

Table 4. Cadmium $\left(\mathrm{mgL}^{-1}\right)$ movement through Mahakanumulla cascade - Feb 2011 Jan 2012

\begin{tabular}{|c|c|c|c|c|c|c|c|c|c|c|c|c|}
\hline \multirow{2}{*}{$\begin{array}{l}\text { Sampling } \\
\text { Points }\end{array}$} & Feb & Mar & April & May & June & July & Aug & Sep & Oct & Nov & Dec & Jan \\
\hline & \multicolumn{11}{|c|}{2011} & 2012 \\
\hline Siw tank & $0.06^{\mathrm{e}}$ & $0_{D}^{0.11^{g}}$ & $0.21^{\mathrm{C}}$ & $0.21^{f}$ & $0.21^{\mathrm{e}}$ & $0.14^{\mathrm{d}}$ & $0.11^{\mathrm{g}}$ & ${ }_{\mathrm{E}}^{0.07^{\mathrm{g}}}$ & $0.11^{\circ}$ & $0.16^{g}$ & $0.13^{f}$ & $\begin{array}{c}0.08^{f} \\
E\end{array}$ \\
\hline field R1 & $\underset{\mathrm{G}}{0.07^{\mathrm{e}}}$ & $0.12^{f}$ & $0.22^{\mathrm{e}}$ & $\underset{\mathrm{AB}}{0.22^{\mathrm{f}}}$ & $0.21^{\mathrm{e}}$ & $0.17^{b c}$ & $0.12^{\mathrm{g}}$ & $\underset{\mathrm{F}}{0.08^{\mathrm{g}}}$ & $\underset{\mathrm{E}}{0.13^{\mathrm{e}}}$ & $0.17^{\mathrm{f}}$ & $\frac{0.14^{f}}{f}$ & $\underset{\mathrm{F}}{0.08^{\mathrm{f}}}$ \\
\hline field R2 & $\underset{\mathrm{H}}{0.09^{\mathrm{d}}}$ & $0.14^{\mathrm{e}}$ & $0.24^{d}$ & $0.24^{\mathrm{e}}$ & $0.22^{\mathrm{e}}$ & $0.18^{\mathrm{bc}}$ & $0.14^{\mathrm{f}}$ & $0.11^{\mathrm{f}}$ & $0.17^{\mathrm{d}}$ & $0.20^{\mathrm{C}}$ & $0.14^{\mathrm{f}}$ & $\underset{\mathrm{FG}}{0.10^{\mathrm{c}}}$ \\
\hline field R3 & $\underset{I}{0.11^{\mathrm{c}}}$ & $\underset{F}{0.18^{\mathrm{cd}}}$ & $\underset{\mathrm{B}}{0.27^{\mathrm{c}}}$ & $\underset{\mathrm{A}}{0.30^{\mathrm{cd}}}$ & $\underset{\mathrm{B}}{0.27^{\mathrm{c}}}$ & $\underset{\mathrm{DE}}{0.20^{\mathrm{b}}}$ & ${ }_{\mathrm{G}}^{0.16^{\mathrm{e}}}$ & $\underset{H}{0.13^{d}}$ & $\frac{0.20^{\mathrm{c}}}{\mathrm{D}}$ & $\frac{0.22^{\mathrm{d}}}{}$ & $\underset{\mathrm{EF}}{0.18^{\mathrm{e}}}$ & $\underset{H}{0.14^{d}}$ \\
\hline Amana tank & $0.11^{\mathrm{c}}$ & $0.16^{d}$ & $0.25^{\mathrm{d}}$ & $0.29^{d}$ & $\underset{B}{0.25^{d}}$ & $\underset{E}{0.14^{d}}$ & $\underset{D}{0.18^{d}}$ & $0.11_{F}^{\text {ef }}$ & $\underset{D}{0.18^{d}}$ & $0.22^{d}$ & $0.20^{\mathrm{de}}$ & $\underset{\mathrm{D}}{0.16^{\mathrm{c}}}$ \\
\hline field R1 & $\underset{\mathrm{H}}{0.11^{\mathrm{c}}}$ & $0.17^{d}$ & $\frac{0.27^{c}}{B}$ & $0.31^{b c}$ & $0.26^{\mathrm{cd}}$ & $0.14^{\mathrm{d}}$ & $\frac{0.20^{\mathrm{c}}}{\mathrm{DE}}$ & $\frac{0.13^{\mathrm{de}}}{}$ & $\frac{0.21^{\mathrm{c}}}{\mathrm{D}}$ & $0.24^{\mathrm{c}}$ & $0.23^{\mathrm{c}}$ & $0.19^{\mathrm{b}}$ \\
\hline field R2 & $0.13^{b}$ & $0.19^{b c}$ & $\underset{\mathrm{B}}{0.30^{\mathrm{b}}}$ & $0.33^{\mathrm{a}}$ & $\frac{0.27^{c}}{\mathrm{c}}$ & $0.15^{\mathrm{cd}}$ & $0.21^{b}$ & ${ }_{\mathrm{H}}^{0.16^{\mathrm{C}}}$ & $0.25^{\mathrm{b}}$ & $\frac{0.26^{b}}{D}$ & $0.27^{\mathrm{b}}$ & $\underset{\mathrm{F}}{0.21^{\mathrm{a}}}$ \\
\hline field R3 & $0.17^{\mathrm{a}}$ & ${ }_{\mathrm{D}}^{0.21^{\mathrm{a}}}$ & $0.32^{\mathrm{a}}$ & $0.32^{\mathrm{ab}}$ & $0.32^{\mathrm{a}}$ & $0.16^{\mathrm{cd}}$ & $0.20^{\mathrm{bc}}$ & $0.19^{b}$ & $0.28^{\mathrm{a}}$ & $0.28^{\mathrm{a}}$ & $\underset{\mathrm{B}}{0.30^{\mathrm{a}}}$ & $\underset{\mathrm{DE}}{0.21^{\mathrm{a}}}$ \\
\hline Maha tank & $0.18^{\mathrm{a}}$ & $\underset{\mathrm{F}}{0.20^{\mathrm{ab}}}$ & $\frac{0.25^{\mathrm{d}}}{\mathrm{D}}$ & $0.31^{\mathrm{bc}}$ & $0.30^{\mathrm{b}}$ & $\underset{\mathrm{E}}{0.23^{\mathrm{a}}}$ & $0.27^{\mathrm{a}}$ & $0.23^{\mathrm{a}}$ & $\underset{B C}{0.29^{\mathrm{a}}}$ & $\frac{0.25^{\mathrm{b}}}{\mathrm{D}}$ & $0.21^{\mathrm{cd}}$ & $0.18^{\mathrm{bc}}$ \\
\hline
\end{tabular}

- Means with same letters are not significantly different. Siw tank -Siwalagala tank, Amana tank-Amanakkatuwa tank, Maha tank-Mahakanumulla tank. (Upper case letters - temporal variation, Lower case letters- spatial variation).

Most of tank thaulla areas in Mahakanumulla cascade used as grassing land for huge cattle and buffalo population. Therefore high load of cattle and buffalo manure and considerable amount of urine are added to tank thaulla. It is also reported that $\mathrm{Cd}^{+2}$ concentration in buffalo and cattle dung varies $0.5-7.8 \mathrm{mgL}^{-1}$ (Wijewardana and Gunarathana et al., 2004). During the rainy period, dissolved heavy metals and other nutrients reach to the tank water. The presence of elevated concentration of $\mathrm{Cd}^{+2}$ in soil and water is greatest concern as a result of the toxicity of $\mathrm{Cd}^{+2}$ and its ability to accumulate in soils, and bio-accumulate in biosphere. 


\section{CONCLUSION}

The concentrations of major plant nutrients; $\mathrm{NO}_{3}{ }^{-}, \mathrm{PO}_{4}{ }^{3-}, \mathrm{K}^{+}$and heavy metal $\mathrm{Cd}^{+2}$ in water samples of the Mahakanumulla cascade showed statistically significant spatial and temporal variations over the twelve months study period. In the temporal changes of nutrients, high amounts of $\mathrm{NO}_{3}^{-}, \mathrm{PO}_{4}^{3-}, \mathrm{K}^{+}\left(5.22,6.07,8.20\right.$ and $0.32 \mathrm{mgL}^{-1}$ respectively) were observed in waters of three tanks and sampling points of paddy tracks just after application of chemical fertilizer during Yala and Maha seasons of which highest concentrations were observed in the months of April and May of the Yala season. And also the temporal changes of concentrations of $\mathrm{NO}_{3}^{-}, \mathrm{PO}_{4}{ }^{3-}, \mathrm{K}^{+}$and $\mathrm{Cd}^{+2}$ in the waters of three tanks and paddy tracks were coincided with bimodal rainfall pattern of the area. Spatial distribution of $\mathrm{NO}_{3}^{-}, \mathrm{PO}_{4}{ }^{3-}$, $\mathrm{K}^{+}$and $\mathrm{Cd}^{+2}$ concentrations in the water of three sampling locations of each paddy track showed significant increasing trend from first point to third sampling point of the paddy field. Therefore, this study also concludes that, there is a tendency to accumulate certain elements in the waters of lower tanks and waters of the lower part of the paddy track of the commanding area as well.

\section{REFERENCE}

Califonia Department of Agriculture (1998) .The transfer of cadmium from agricultural soils to the human food chain. Biochemistry of trace metals .Lewis publishers.Adriano.pp.109158.

Chun G.Y., Jong, H.H and Jeon, J.H. (2003). Mass balance analysis in Korean paddy rice culture .Paddy Water Environ.1, 99-103.

Dharmasena,P.B. (2004).Small tank heritage and current problems. Procedings of Symposium Hector Kobbekaduwa Agrarian Research and Traning Institute. Pp. 1-18.

Dissanayake, C.B., Weerasuriya, S.V.R and Silva, S.G.H .(1982). The environmental chemistry of Mahaweli River. Sri Lanka Int.J.Env.Studies, 78, 207-293.

Gunawardhana, H.D . and Kumauni,R. N. (1980). Studies on quality of irrigation water under Kalawewa area. Journal National Science Council. Sri Lanka 9 ,2.

Hill, A.R. (1996). Nitrate removal in stream ripararian zone. J Environ Qual 25, 743-755.

Lamontagne, S., Herczeg, A., Leaney, F., Dighton, J., Pritchard, J., Ullman ,W. and Jiwan, J. (2001).Nitrogen attenuation by stream riparian zones: Propects for Australian landscapes. Presented at the Murray Darling Basin commission Ground water workshop.Victor Harbour, South Australia.

Mclaughlin, M.J., Tiler, K.G., Naidu, R. and Stevens, D.P. (1996) .The behaviour and environmental impacts of contaminants in fertilizers. Aust.J.soil.Res.34, 1-54.

Panabokke, C.R. (2002) .The Small tank cascade systems of Rajarata: Their setting, distribution patterns, and Hydrography. International Water resource Management Institute, Colombo, Sri Lanka. Pp 7-8 
Panabokke, C.R., Sakthivadivel, R .and Weerasinghe, A.S. (2001). Small tanks in Sri Lanka: Evolution, Present status and issues. International Irrigation Management Institute, Colombo, Sri Lanka.pp 5-12.

Wijesundara ,W.M.G.D., Nandasena, K.A and Jayakody, A.N. (2011a). Accumulation of plant nutrients and their fluctuation together with changes of several water quality parameters of three selected tanks in Mahakanumulla cascade of dry zone, Sri Lanka. Water professional day Symposium.2011. University of Peradeniya.pp 43-51.

Wijesundara,W.M.G.D., Nandasena, K.A. and Jayakody, A.N.(2011b). Temporal variation of plant nutrients and some water quality parameters in Meegassagama tank .Proceedings of the $10^{\text {th }}$ International conference of the East and Southeast Asia federation of Soil Science Societies.pp.65-66.

Wijesundara, W.M.G.D., Nandasena, K.A.and Jayakody, A.N. (2011b). Temporal Variation of Nitrate and Phosphate in Selected Six Small Tanks of Dry Zone of Sri Lanka. Tropical Agricultural Research. Vol. 23 (3): Pp277 -282.

WHO.(2004).Guideline for drinking water quality, 3(1).Geneva: World Health Organization.pp.317.

Wijewardana, J.D.H. and Gunarathna, S.P. (2004). Heavy metal contents in commonly used animal manures. Annals of the Sri Lanka Department of Agriculture.6, 245-253.

Young, S.M., Pitawala, A. and Gunathilaka, J. (2010). Fate of phosphate and nitrate in waters of an intensive agricultural area in the dry zone of Sri Lanka. Paddy water Environ 8,71-79. 